\title{
Implementation of Cloud Computing Using the Roadmap for Cloud Computing Adoption (ROCCA) Method in Non-Ministry Government Institutions (Case Study of Lembaga Ilmu Pengetahuan Indonesia)
}

\author{
Tony Haryanto \\ Universitas Gunadarma \\ E-mail: haryanto.tony@gmail.com
}

(Received: April-2019; Reviewed: May-2019; Accepted: July-2019;

Avalaibel Online: August-2019; Published: September -2019)

This is an open access article distributed under the Creative Commons Attribution License CC-BY-NC-4.0 (C2019 by author (https://creativecommons.org/licenses/by-nc/4.0/)

\begin{abstract}
Cloud computing answers some of the challenges in the ICT world, including the high investment that must be spent. This study aims to examine the adoption of the Roadmap for Cloud Computing Adoption model used for cloud computing implementation at the Indonesian Institute of Sciences. This research model uses cloud computing analysis along with each phase of ROCCA and compared with conditions in Non-Ministry Government Institutions (LPNK). The results of this study are a modification of the adoption model of ROCCA, which consists of 5 (five) stages, namely the Analysis, Design, Adoption, Migration, and Management stages. Then it resulted in the implementation of cloud computing with the implementation model of Private Cloud as a service and Infrastructure as a Service service for research institutions at the Indonesian Institute of Sciences. The implementation of cloud computing at LIPI can run well.
\end{abstract}

Keywords: Cloud computing; Private cloud as a service (PaaS); Infrastructure as a Service (IaaS); adoption model, ROCCA.

\section{INTRODUCTION}

Cloud computing answers some of the challenges in the ICT world, including the high investment that must be spent if you build your own central server, the high demands of each user, especially organizations engaged in data with rapid fluctuations, other challenges namely the impact of disasters due to rapid selection (Alim \& Cancer, 2016; Herwin, 2011; Kadir \& Triwahyuni, 2014; Mulyani, 2011; Mutia, 2016; Syaikhu, 2010). Many aspects must be considered using cloud computing, namely internet availability, service guarantees, data security and privacy, adequate data backups, costs, etc. (Eko Setia Pinardi, 2011; Erick Kurniawan, 2016; Raziq \& Marlina, 2018; Setiawan, 2017) 
The implementation of cloud computing is done systematically so that the adoption model is needed to analyze and provide steps in the process of implementing cloud computing (Anggeriana, 2012; Ika Kusuma, 2016; Masruroh, Suciasih, \& Suseno, 2015). There needs to be an analysis of the available adoption models and changes made to fit the research object. The adoption model that will be used as a reference Roadmap for Cloud Computing Adaption (ROCCA). Further explained Roadmap for Cloud Computing Adoption (ROCCA) is a generic model that is based on research on matters related to the adoption of cloud computing. Because it is generic, this model can be applied to several cloud computing domains, in any organization and any cloud platforms and infrastructure. Therefore, this opens up opportunities to utilize the ROCCA framework in various forms of organizations including research institutions, in this case, the Lembaga Ilmu Pengetauan Indonesia (LIPI).

\section{METHOD}

The stages of the research began with problem identification, problem analysis, choosing the cloud computing method, then collecting the data afterward the ROCCA method. The problem that occurred at LIPI was accidental work accident (force majeure) which caused the burning of server space. It took several weeks to restore IT services at LIPI. Learning from this incident, a solution was sought to overcome this problem, cloud computing technology. LIPI requires a method for carrying out steps in cloud computing IT services throughout LIPI. One method related to cloud computing is the Roadmap for Cloud Computing (ROCCA) method. The stage before analysis is carried out by collecting data related to the cloud computing IT service plan at LIPI. Data collection was carried out by interviewing the LIPI General Bureau, represented by the Head of the Sub-Section managing and maintaining the information technology network. The analysis phase is intended to find out what needs are needed, LIPI requires technology that can meet the needs of both software and hardware developments. Cloud computing can be used to overcome problems on the condition that it can overcome the problem of hardware and software development, data storage capacity, the recovery process can be carried out quickly, increasing the capacity of hardware or software in accordance with needs.

\section{RESULT AND DISCUSSION}

This study aims to make an analysis and build cloud computing by referring to the adoption of the Roadmap for Cloud Computing Adoption (ROCCA) model implemented at the Indonesian Institute of Sciences. LIPI has cleared computing IT services throughout LIPI due to work accident factors that caused the Data Center at LIPI Center to catch fire. On the basis of that experience, LIPI decided to cloud computing all information technology services.

\section{Analysis with the Roadmap For Cloud Computing (ROCCA) Method}

The analysis phase in the Roadmap for cloud computing (Rocca) model is a generic (general) cloud computing adoption model so that it can be implemented in a variety of conditions. It can be verified by analysis, design, adoption, migration and processing stages.

\section{Analysis Phase Using SWOT}

The strategy of using strengths and opportunities aims to provide convenience, certainty, especially in management and development budgets. LIPI has given permission to click on IT 
services. And change the mindset that assets must be in the form of hardware (hardware) into service.

The need for bandwidth will continue to increase, certainly will affect the price of the bandwidth itself. Bandwidth management is done. Security standards from the cloud computing service provider and LIPI itself, see the security guarantee standards and training in the field of network security to human resources.

Providers provide guarantees to provide the desired safety factor by the user. There is a Bureau appointed to conduct training or management of this cloud computing. Can choose cloud computing provides services without being tied to one provider.

Enhance the training of human resources to overcome impending security threats. Appoint the General Bureau as the manager of cloud computing, assisted by experts who are specialized in helping in the field of network security

\section{Design Stage}

This phase will discuss 3 (three) main ideas, namely the selection of cloud infrastructure, budget planning, and the adoption and migration planning process.

LIPI must choose a cloud service model that suits the needs identified at the analysis stage. There are three models of cloud computing services to choose from namely Software as a Service (SaaS), Platform as a Service (PaaS), and Infrastructure as a Service (IaaS). In addition to the implementation, the model can choose Private Cloud or Public loud.

Table 1.

Cloud Computing Service Models (Hamzah, 2012)

\begin{tabular}{|c|c|c|}
\hline Service Model & $\begin{array}{c}\text { Aplication } \\
\end{array}$ & $\begin{array}{r}\text { Function } \\
\end{array}$ \\
\hline Saas & $\begin{array}{l}\text { Email, CRM, online storage, online } \\
\text { document }\end{array}$ & $\begin{array}{l}\text { Communication, } \\
\text { collaboration, promotion }\end{array}$ \\
\hline PaaS & $\begin{array}{l}\text { Web server, development tools, } \\
\text { database. }\end{array}$ & Application development \\
\hline
\end{tabular}

Based on the analysis phase, among others, support for the implementation of cloud computing and the condition of IT infrastructure along with the hardware requirements, especially servers at LIPI that produce an analysis strategy and determine the form of cloud computing service model that is focused on providing the infrastructure above, the service model chosen is Infrastructure as a Service ( IaaS) with Private Cloud as the implementation model.

The budget design is carried out effectively and efficiently in financing virtual private dedicated machines.

Table 2.

Details of virtual private machine specifications

\begin{tabular}{ccc}
\hline No & Type & Capacity \\
\hline $\mathbf{1}$ & CPU $=48$ core $(@ 2,5 \mathrm{Ghz})$ & $120 \mathrm{GHz}$ \\
$\mathbf{2}$ & Memory $=696 \mathrm{VRam}(\mathrm{GB})$ & $696 \mathrm{~GB}$ \\
$\mathbf{3}$ & Storage $=17 \mathrm{~TB}$ vHDD & $17,408 \mathrm{HDD}$ \\
\hline
\end{tabular}

LIPI conducts cloud computing as a whole from hardware, software application materials, all centered on the data center (Data Center). Because LIPI has work units spread throughout Indonesia, it is necessary to create a LIPI network scheme. Because LIPI has cleared all IT services including Routers, Switches, Servers. Regarding the LIPI Private cloud network scheme can be shown in Figure 1 


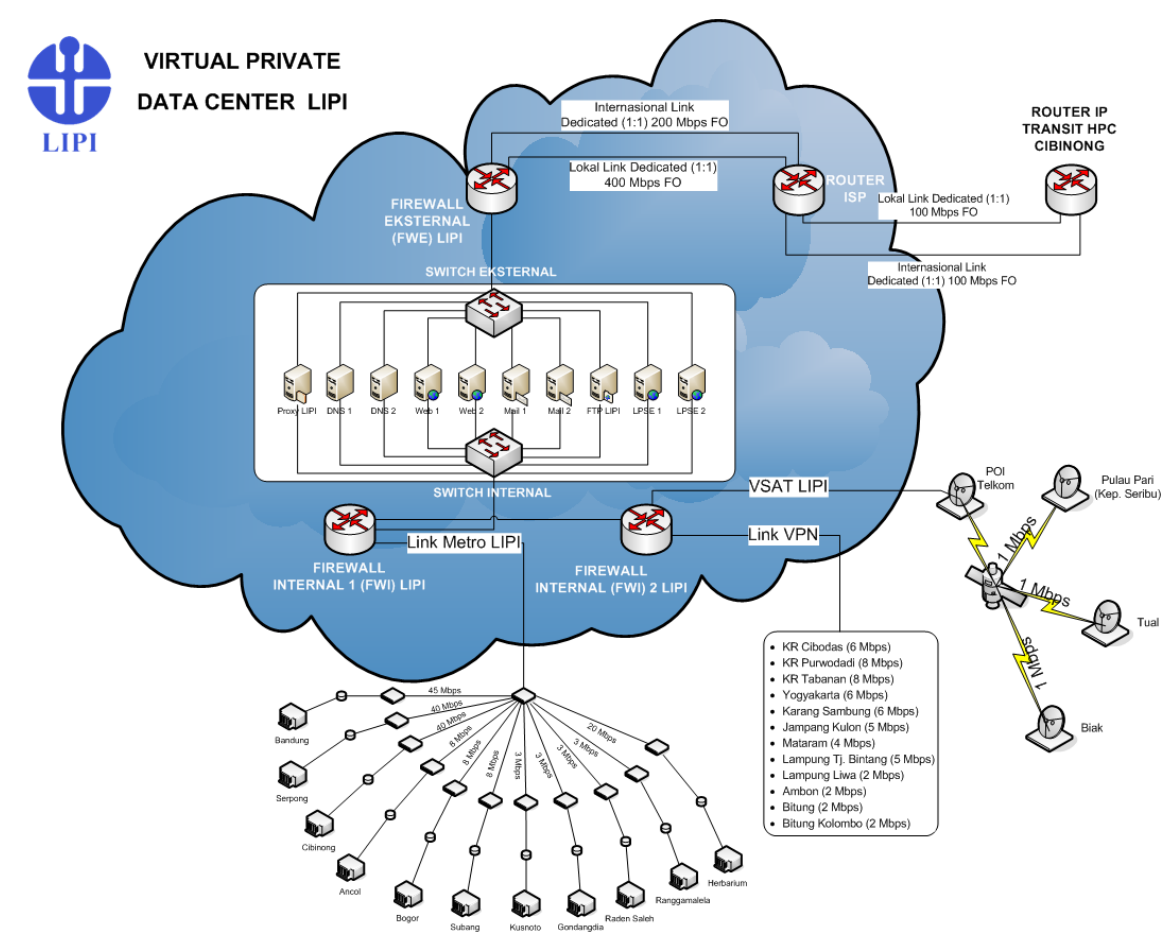

Figure 1 .

Virtual private Data center LIPI

LIPI has a dedicated International Link (1: 1) 200 Mbps Fiber optic, dedicated local link (1: 1) $400 \mathrm{Mbps}$ Fiber optic, then goes to an external Firewall (FEW), ISP Router is subdivided 100 Mbps for International links and 100 Mbps Local dedicated links are forwarded to Cibinong's HPC transit IP Router. What enters the LIPI external firewall (FWE) is forwarded to an external switch before being distributed to servers. The servers before being accessed by work units throughout LIPI must go through the internal firewall 1 (FWI) of LIPI, access to Vsat LIPI using POI, Telkom Link divided to work units such as Pari Island, Tual, Biak which cannot use optical optics of 1 Mbps, while the VPN Link to several work units (sicker).

Table 3.

Distribution of WAN work unit connections

\begin{tabular}{llcl}
\hline No & \multicolumn{1}{c}{ Satuan Kerja } & Bandwith & Service \\
\hline 1 & Data Connection-ISP Bandung & $45 \mathrm{Mbps}$ & Metro \\
\hline 2 & Data Connection -ISP Serpong & $40 \mathrm{Mbps}$ & Metro \\
\hline 3 & Data Connection -ISP Cibinong & $40 \mathrm{Mbps}$ & Metro \\
\hline 4 & Data Connection -ISP Ancol & $5 \mathrm{Mbps}$ & Metro \\
\hline 5 & Data Connection -ISP Bogor & $8 \mathrm{Mbps}$ & Metro \\
\hline 6 & Data Connection -ISP Subang & $8 \mathrm{Mbps}$ & Metro \\
\hline 7 & Data Connection -ISP Kusnoto & $3 \mathrm{Mbps}$ & Metro \\
\hline 8 & Data Connection -ISP Gondangdia & $3 \mathrm{Mbps}$ & Metro \\
\hline 9 & Data Connection -ISP Raden Saleh & $3 \mathrm{Mbps}$ & Metro \\
\hline 10 & Data Connection -ISP Rangga Malela & $3 \mathrm{Mbps}$ & Metro \\
\hline 11 & Data Connection -ISP Herbarium & $20 \mathrm{Mbps}$ & Metro \\
\hline
\end{tabular}


Table 4.

VPN Connection

\begin{tabular}{clcc}
\hline No & \multicolumn{1}{c}{ Satuan Kerja } & Bandwith & Service \\
\hline 1 & Kebun Raya Cibodas & $6 \mathrm{Mbps}$ & Metro \\
\hline 2 & Kebun Raya Purwodadi & $8 \mathrm{Mbps}$ & Metro \\
\hline 3 & Kebun Raya Tabanan & $8 \mathrm{Mbps}$ & Metro \\
\hline 4 & Yogyakarta & $6 \mathrm{Mbps}$ & Metro \\
\hline 5 & Karang Sambung & $6 \mathrm{Mbps}$ & Metro \\
\hline 6 & Jampang Kulon & $5 \mathrm{Mbps}$ & Metro \\
\hline 7 & Mataram & $4 \mathrm{Mbps}$ & Metro \\
\hline 8 & Lampung Tj Bintang & $5 \mathrm{Mbps}$ & Metro \\
\hline 9 & Lampung Liwa & $2 \mathrm{Mbps}$ & Metro \\
\hline 10 & Ambon & $2 \mathrm{Mbps}$ & Metro \\
\hline 11 & Bitung & $2 \mathrm{Mbps}$ & Metro \\
\hline 12 & Bitung Kolombo & $2 \mathrm{Mbps}$ & Metro \\
\hline
\end{tabular}

Table 5.

VSAT Connection

\begin{tabular}{c|lcc} 
NO & Work unit & BANDWITH & SERVICE \\
\hline 1 & Pulau Pari & $1 \mathrm{Mbps}$ & Metro \\
2 & Tual & $1 \mathrm{Mbps}$ & Metro \\
3 & Biak & $1 \mathrm{Mbps}$ & Metro \\
\hline
\end{tabular}

\section{Adoption Stage}

The adoption phase is the third phase of ROCCA (Shimba, 2010). Nimoko (2012) said that the adoption phase is a preparation by integrating and adjusting applications and data that will be migrated with the intended platform and infrastructure. This stage must be able to ensure that applications will be able to function in the new infrastructure and still be able to operate with applications that are not migrated. Then if all the preparations have been made then the migration phase can be done using all the plans that have been prepared. Some applications are at the adoption and migration stages

To manage cloud computing, software is needed to manage it. There is software that can manage VMware VSphere cloud computing, Windows Hyper-V, Citrix Xen Server, Proxmox VE, and Ubuntu OpenStack. Based on the consideration of a limited implementation budget, system requirements and the ability of personnel to cloud computing technology, the software used for this implementation is VMware ESXi 6.0 (OS VMware). The reason for choosing VMware ESXi 6.0 software (VMware OS), this software is built-in from VMware and can be directly installed on the hardware and the cloud computing service provider has provided it for free.

To manage cloud computing LIPI has a configuration that must be fulfilled by cloud computing service providers, servers

In the network configuration in LIPI, it does not use a cluster configuration, the topology used uses the star topology, all work units lead to servers that have been cloud computing.

In the LIPI virtual private cloud infrastructure, it is seen that all work units in LIPI access to servers that have been cloud computing as in the picture above as well as the LIPI cloud 
network configuration where all work units in LIPI access servers then will pass through the firewall, switch, router as in the LIPI virtual cloud configuration.

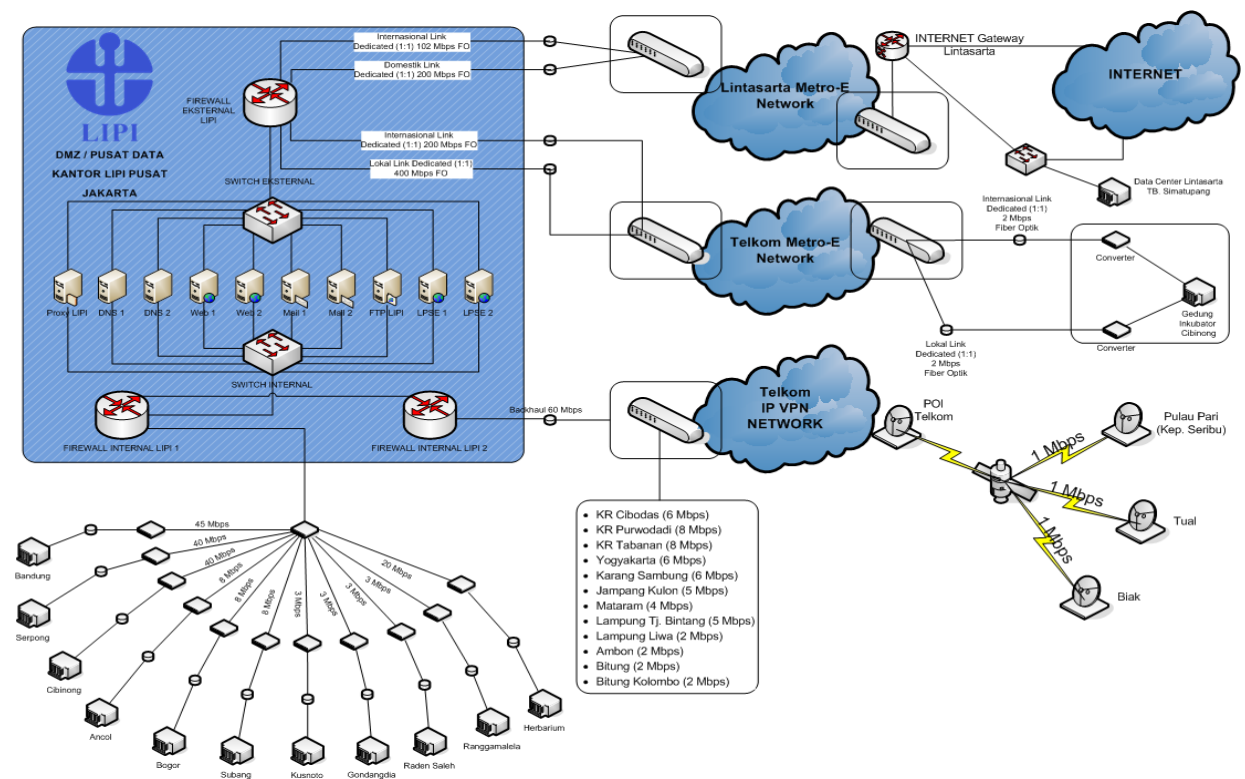

Figure 2.

LIPI Cloud network topology

The application and data integration stage is done after the cloud network infrastructure has been built. In the beginning, LIPI IT services were carried out conventionally with server services physically located in the server room at the Central LIPI. Then the application integration process is done by moving applications and data with the backup method from the old server to the new server that is on to perform the process of restoring applications and data to a server that has been cloud computing. After the users, in this case, the LIPI members in all work units ensure that applications and data can be used. Technically, the application and data integration process time is carried out together with the stakeholders. There are several applications that will experience the migration process which is a product of the LIPI work unit and the LIPI General Bureau is the party responsible for network infrastructure and the administrator of cloud computing.

\section{Migration Stage}

The application and data migration phase is done after the cloud infrastructure that is built has been completed. There are several applications that need to be migrated accordingly Basically that the LAN WAN LIPI infrastructure has run before where all applications are running on their own servers without any interdependencies, the migration process is done by moving the server and data by means of a backup method from a conventional server to a virtual server. That's after the virtual server is ready, then the OS installation is the same as before it was migrated, likewise with the application before it was migrated. If the data migration is left to synchronize the data, the domain only needs to redirect to the new one. 


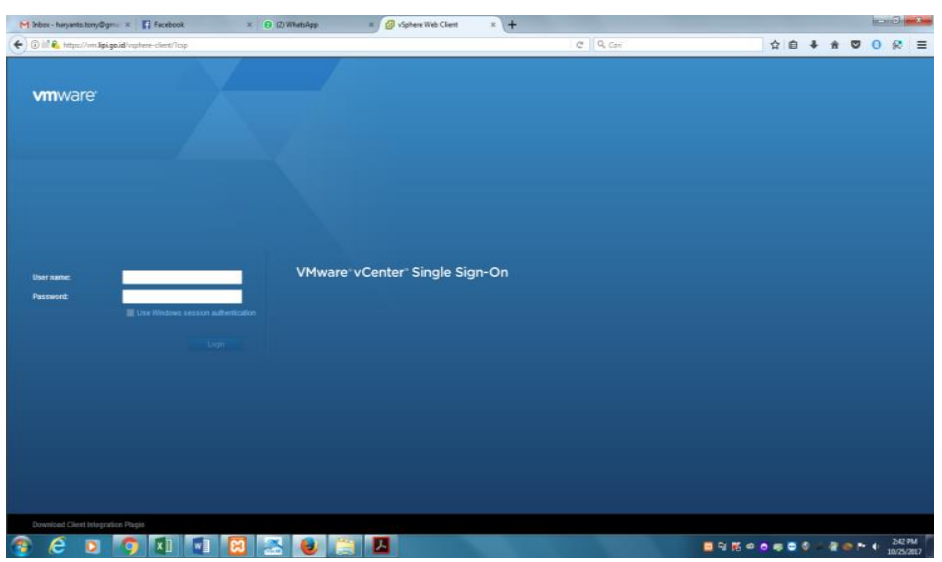

Figure 3.

Virtual server

After the virtual server is available, then log in to the virtual server by configuring and restoring the data to the virtual server. After ensuring the server migration process is complete, the transfer process is done through the virtual server.

Stage of adoption plan implementation must be able to ensure that applications will be able to function in the new infrastructure and still be able to operate with applications that are not migrated. Then if all the preparations have been made then the migration phase can be done using all the plans that have been prepared. After making sure the server is ready to use, the next step is to start the VMware installation and set up the LIPI network environment. Virtual server installation can be seen in

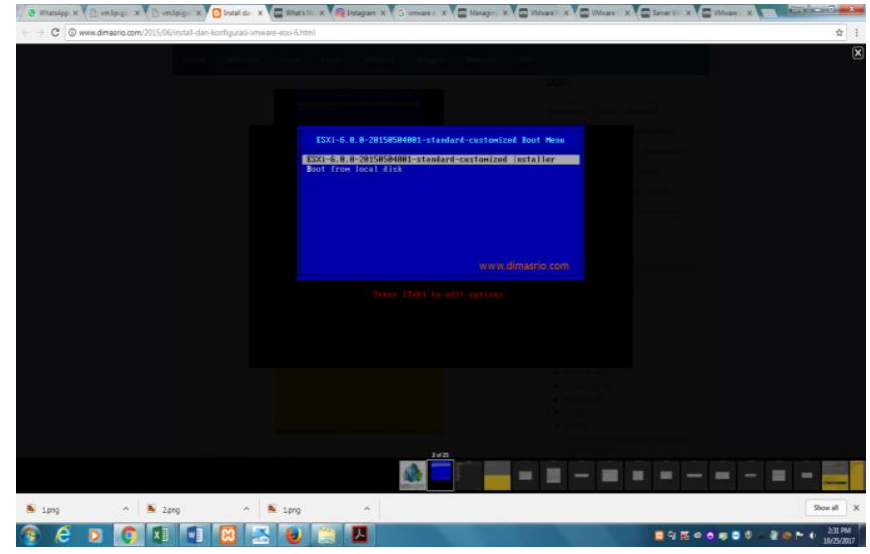

Figure 4.

The Vmware installation process

At the beginning of the Vmware 6.0 standard customized installer installation process there are two choices: Esxi 6.0 standard customized installer and boot from disk, then press Enter 


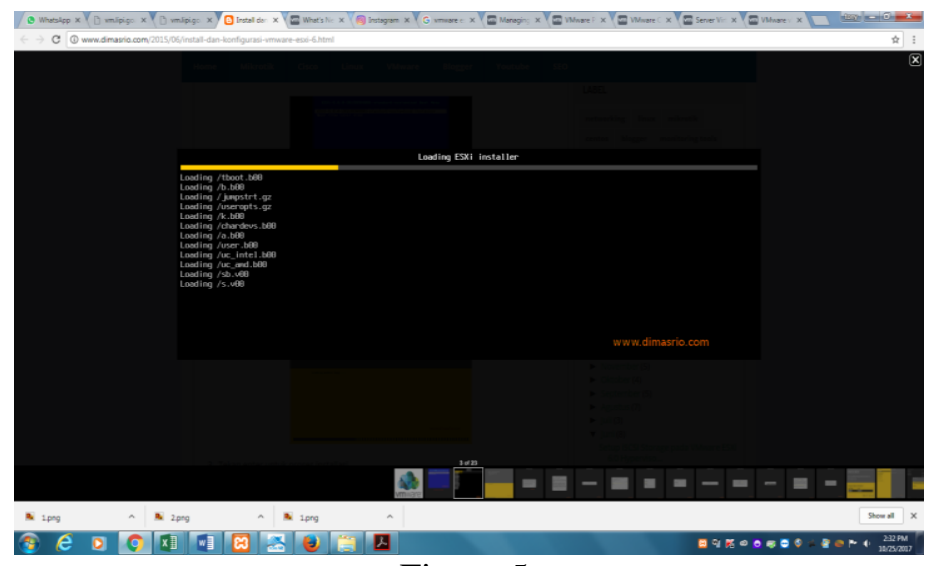

Figure 5

Esxi Installer Loading Process

The process of loading esxi files does not take long after loading the Esxi module

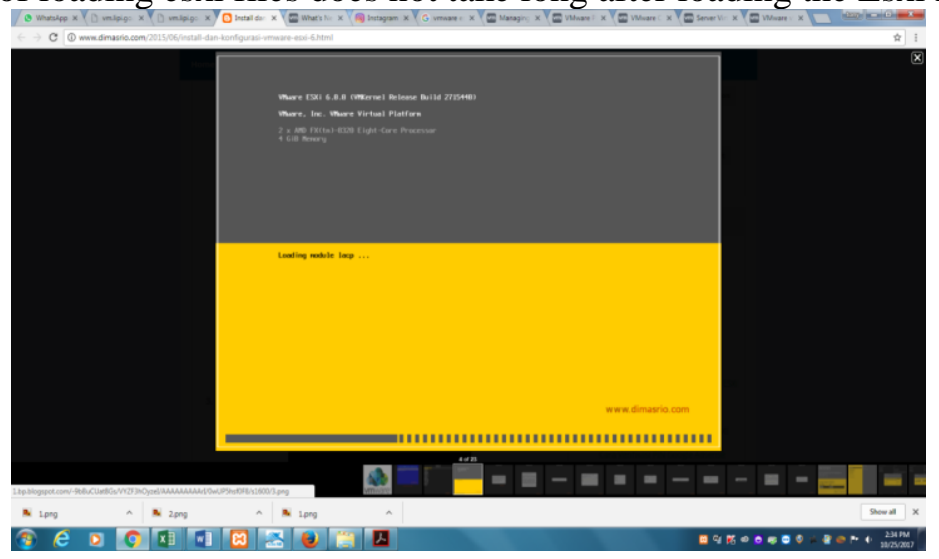

Figure 6.

The module loading process

After that, the process of Esxi modules can take place

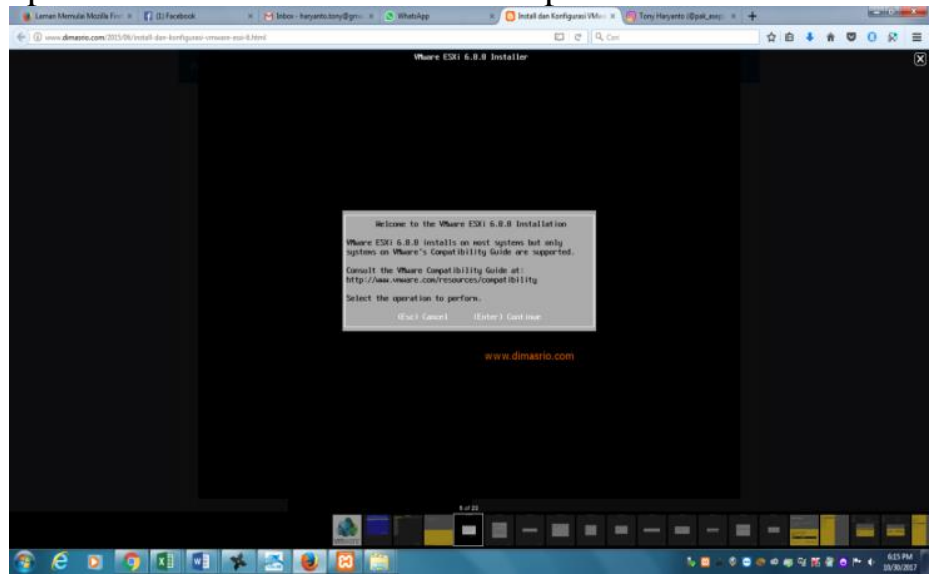

Figure 7.

Entering the VMware Installation process 
Vmware Installation Process

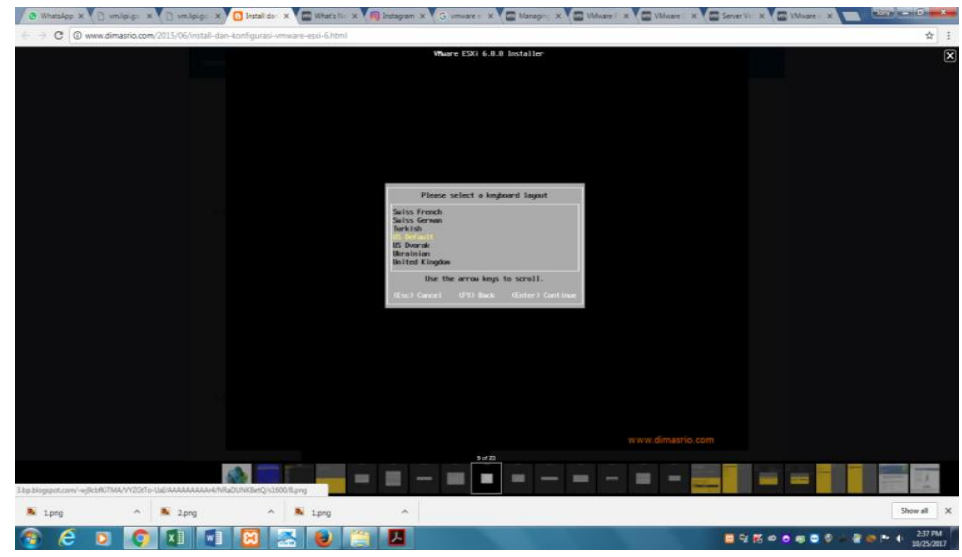

Figure 8.

Select the hard drive allocation to be installed

Next, select the disk allocation that is the target install.

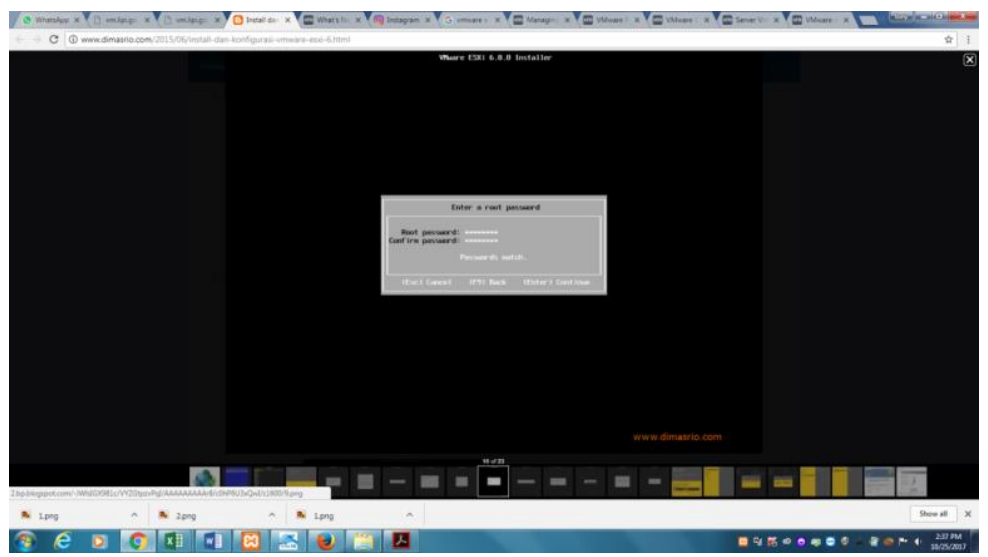

Figure 9.

Filling in the root password

Set the root password which will be used to log into esxi.

Select "Remove the Installation disk before rebooting". Then enter. 
Volume 3, Issue 1, September, 2019 Page. 69- 84

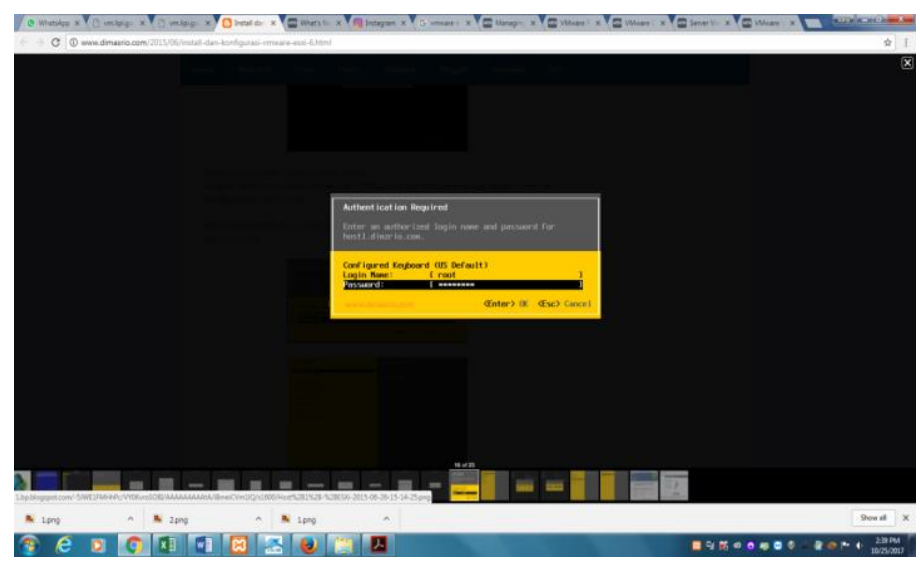

Figure 10.

Remove installation before rebooting

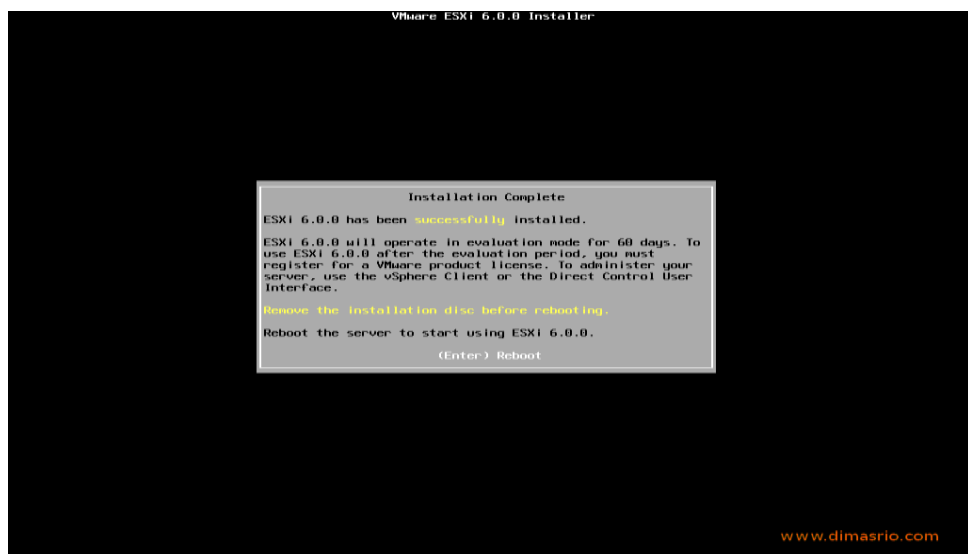

Figure 11.

Fill in the root password

After you reboot, press the "F2" button and you will be asked to enter the root password.

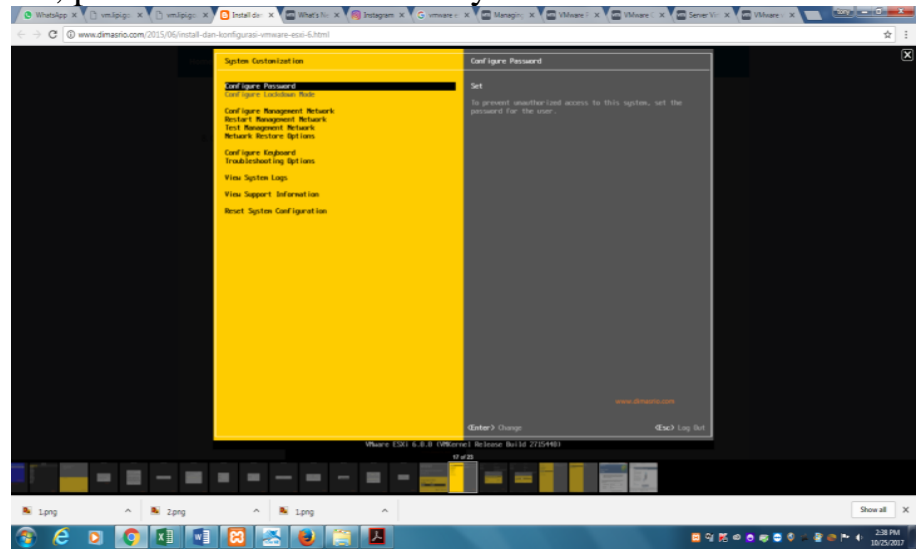

Figure 12

Configure Management Network "->" IPv4 Configuration ". 
After entering "system costomization" select "Configure Management Network" -> "IPv4 Configuration".

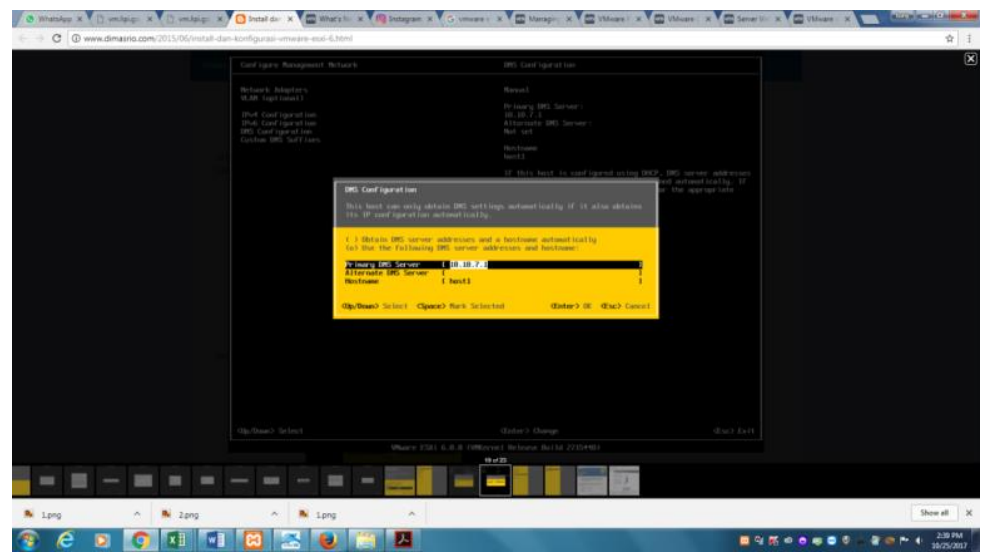

Figure 13.

DNS Configuration

After entering the server management configuration menu, then the DNS configuration can be

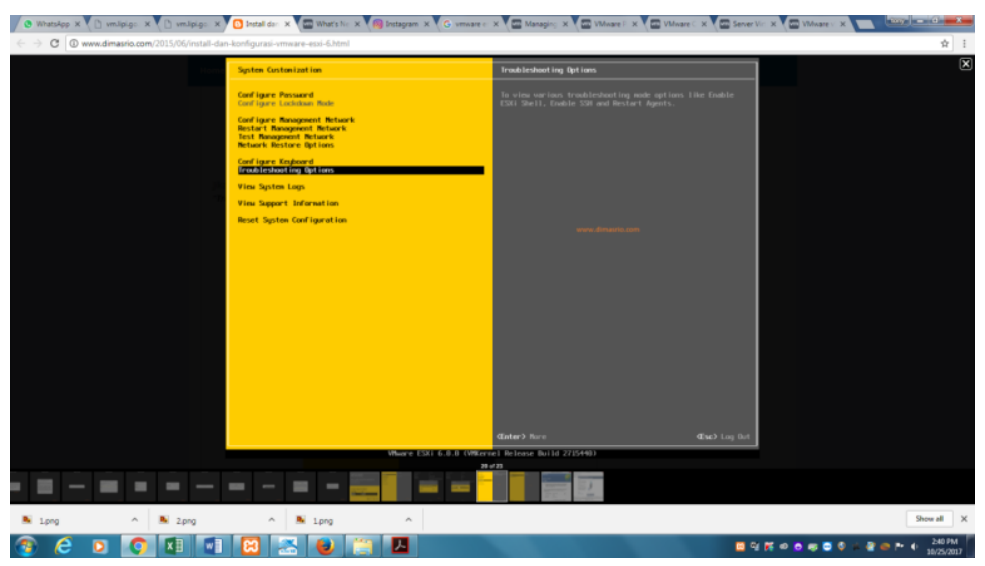

Figure 14.

System Customization -> Troubleshooting Options

If you want to enable SSH on VMware Esxi, go to "System Customization" -> "Troubleshooting Options". 


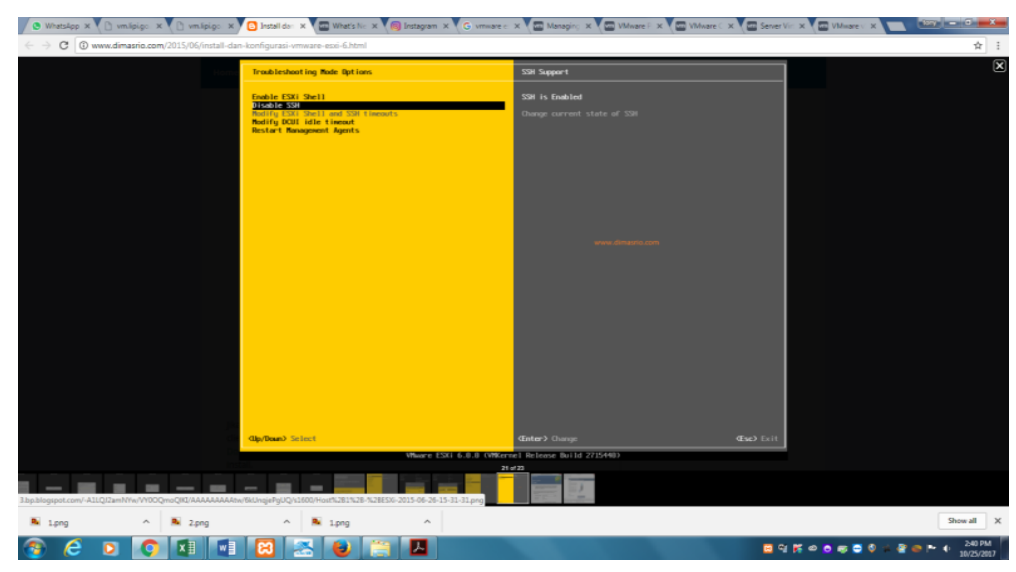

Figure 15.

Completed

If the network configuration is complete, then try Esxi remote using vspare client.

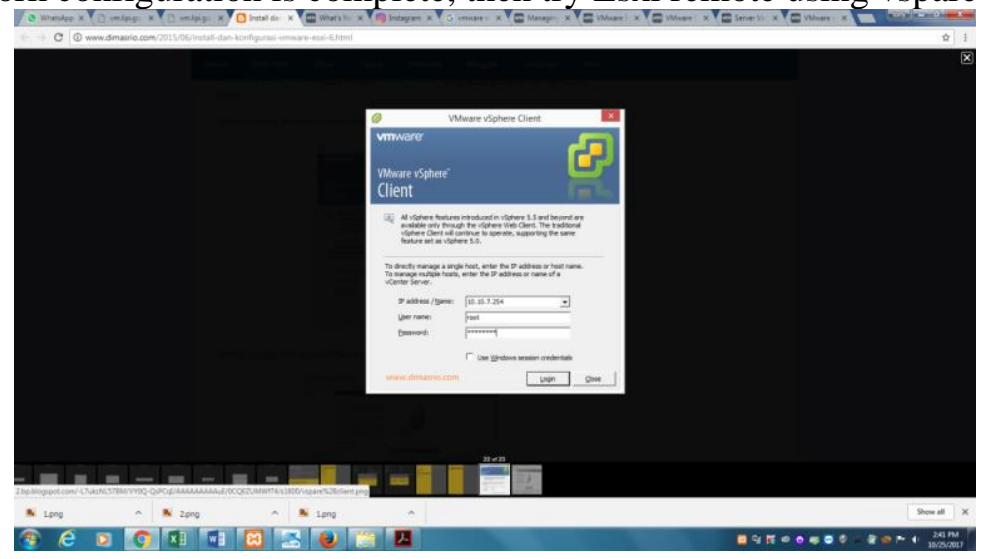

Figure 16

Login and ESXI user interface

Once installed, run vspare client and enter the password that you previously set.

After the virtual server is available, then log in to the virtual server by configuring and restoring the data to the virtual server. After ensuring the server migration process is complete, the transfer process is done through the virtual server.

Based on the beginning of the LIPI network infrastructure where servers are stored in a conventional server room, including applications and data stored on their own without the interdependence of one another. The migration process is done by backing up the old server to the new server that has been cloud computing. After the migration process has been carried out to cloud computing servers, the restore process can be done to new servers.

\section{Management Stage}

At this stage, it means that the process of implementing a Private Cloud with the Infrastructure as a Service (IaaS) service model has been successfully carried out. The server and data migration process is complete with the indication that the application can be accessed again by the user and the data moved has no difference with the previous data. The next step is to 
provide VMware administrator access to the TGTIK LIPI Team and provide assistance for the process of managing cloud infrastructure in the LIPI Campus environment, assisted by expert staff who can assist the management process.

This VMware dashboard is an application that has been provided by the cloud computing service provider to monitor the management of the LIPI cloud network infrastructure. A green status indicates that the virtual server is running in good condition, while the red one is warning or interrupted. The adoption of the Road Cloud For Cloud Computing Adaption (ROCCA) model is very helpful in implementing the cloud computing implementation process at LIPI. The steps formulated in the ROCCA model also make it easier to carry out the implementation process systematically. The analysis phase at ROCCA helps to focus on the main needs and capabilities of the LIPI then the results are used at the design stage to select cloud technology, design budgets, and design adoption and migration strategies before implementing further cloud computing. At the implementation stage, ROCCA divides the process into two stages (adoption and migration). The adoption phase focuses on the preparation for installation and configuration of the cloud infrastructure until it is ready for use, while the migration phase is to move applications from the old server to the cloud infrastructure

At the infrastructure management assistance stage, after all, servers, applications, and data that have been clouded have successfully migrated, the next stage of the trial process is from cloud computing itself. During the trial process, the LIPI General Bureau provided assistance to the work unit network managers.

During the cloud computing process, there should be documentation, a record of how the process works. But it is unfortunate, due to the fact that LIPI is doing cloud computing due to the Force Majeure factor due to the fire in the server room, it must be overcome as soon as possible. Manuals on how the cloud computing process is also not available, just rely on browsing the internet for knowledge about cloud computing.

\section{CONCLUSION}

Lembaga Ilmu Pengetahuan Indonesia (LIPI) can implement cloud computing by following the 5 (five) stages of the ROCCA model modification namely the Analysis, Design, Adoption, Migration, and Management stages that produce Private Cloud Computing and Infrastructure as a Service (IaaS). The application of the Roadmap for Cloud Computing Adaption (ROCCA) as an adoption model can be applied to the Lembaga Ilmu Pengetahuan Indonesia (LIPI), which can be modified according to needs so that it can be implemented properly.

\section{REFERENCES}

Alim, Z., \& Cancer, Y. (2016). Meningkatkan Keamanan Data Cloud Computing Menggunakan Algoritma Vigenere Cipher Modifikasi. Times.

Anggeriana, H. (2012). Pengembangan Elemen Cloud Computing Dalam Sistem Teknologi Informasi. SSRN Electronic Journal. https://doi.org/10.2139/ssrn.2130364

Eko Setia Pinardi. (2011). Menuju Pembangunan Pertanian Berkelanjutan Melalui Cloud Computing. e-Indonesia Initiative 2011 (eII2011) Konferensi Teknologi Informasi dan Komunikasi untuk Indonesia 14-15 Juni 2011, Bandung kemungkinan pengecualian terbatas terhadap pengaturan konfigurasi aplikasi pengguna tertentu. 2. Cloud Platform as a Service (PaaS.

Erick Kurniawan, R. (2016). Migrasi Aplikasi Multitenancy Pada Layanan Komputasi Awan. 


\section{Pinisi Discretion Review \\ Volume 3, Issue 1, September, 2019 Page. 69- 84}

\section{Computing.}

Herwin, A. (2011). Cloud Computing (Komputasi Awan). In Jurnal Teknik Informatika.

Ika Kusuma. (2016). Cloud Computing: Perbedaan SaaS, PaaS, dan IaaS (Kelebihan dan Kekurangan) $\mid$ Daily in Informatics.

Kadir, A., \& Triwahyuni, T. (2014). Pengantar Teknologi Informasi Edisi Revisi. In Andi Yogyakarta. https://doi.org/10.13140/2.1.4734.7840

Masruroh, S. U., Suciasih, S. E., \& Suseno, H. B. (2015). Layanan Teknologi Informasi Cloud Computing Pada Bank Sampah Melati Bersih. Jurnal Teknik Informatika.

Mulyani. (2011). Manajemen Resiko dalam Penerapan Cloud Computing. e-Indonesia Initiative.

Mutia, I. (2016). Pemanfaatan Komputasi Awan (Cloud Computing) Bagi Pembelajaran Mahasiswa Perguruan Tinggi. STRING (Satuan Tulisan Riset dan Inovasi Teknologi). https://doi.org/10.30998/string.v1i1.963

Raziq, A., \& Marlina, E. (2018). Pengelolaan Data Penelitian berbasis Komputasi Awan. SoSDict : Jurnal Pengabdian Masyarakat.

Setiawan, A. B. (2017). Perancangan Sistem Absensi Siswa Menggunakan Sidik Jari Dan Sms Gateway Berbasis Cloud Computing. Perancangan Sistem Absensi Siswa Menggunakan Sidik Jari Dan Sms Gateway Berbasis Cloud Computing.

Syaikhu, A. (2010). Komputasi Awan (Cloud Computing) Perpustakaan Pertanian. Pustakawan Indonesia. 